\title{
A Geochemical Approach to Determine Sources and Movement of Saline Groundwater in a Coastal Aquifer
}

\author{
by Robert Anders ${ }^{1}$, Gregory 0. Mendez ${ }^{2}$, Kiyoto Futa ${ }^{3}$, and Wesley R. Danskin ${ }^{2}$
}

\begin{abstract}
Geochemical evaluation of the sources and movement of saline groundwater in coastal aquifers can aid in the initial mapping of the subsurface when geological information is unavailable. Chloride concentrations of groundwater in a coastal aquifer near San Diego, California, range from about 57 to $39,400 \mathrm{mg} / \mathrm{L}$. On the basis of relative proportions of major-ions, the chemical composition is classified as $\mathrm{Na}-\mathrm{Ca}-\mathrm{Cl}-\mathrm{SO}_{4}, \mathrm{Na}-\mathrm{Cl}$, or $\mathrm{Na}-\mathrm{Ca}-\mathrm{Cl}$ type water. $\delta^{2} \mathrm{H}$ and $\delta^{18} \mathrm{O}$ values range from $-47.7 \%$ to $-12.8 \%$ and from $-7.0 \%$ o to $-1.2 \%$, respectively. The isotopically depleted groundwater occurs in the deeper part of the coastal aquifer, and the isotopically enriched groundwater occurs in zones of sea water intrusion. ${ }^{87} \mathrm{Sr} /{ }^{86} \mathrm{Sr}$ ratios range from about 0.7050 to 0.7090 , and differ between shallower and deeper flow paths in the coastal aquifer. ${ }^{3} \mathrm{H}$ and ${ }^{14} \mathrm{C}$ analyses indicate that most of the groundwater was recharged many thousands of years ago. The analysis of multiple chemical and isotopic tracers indicates that the sources and movement of saline groundwater in the San Diego coastal aquifer are dominated by: (1) recharge of local precipitation in relatively shallow parts of the flow system; (2) regional flow of recharge of higher-elevation precipitation along deep flow paths that freshen a previously saline aquifer; and (3) intrusion of sea water that entered the aquifer primarily during premodern times. Two northwest-to-southeast trending sections show the spatial distribution of the different geochemical groups and suggest the subsurface in the coastal aquifer can be separated into two predominant hydrostratigraphic layers.
\end{abstract}

\section{Introduction}

World population centers tend to concentrate in coastal areas, and many of these population centers rely on groundwater to supplement their surface-water supplies for domestic and agricultural consumption. The occurrence of saline groundwater in coastal aquifers, however, can limit the use of this local resource. Many studies in coastal aquifers have focused on sea water intrusion as the source of high-salinity groundwater, and the process and mechanism of sea water intrusion are well understood (Richter and Kreitler 1993; Bear et al. 1999). Although saline groundwater can result from recent sea water intrusion induced by groundwater pumping, other sources of salinity in coastal aquifers are not directly related to sea water intrusion. These other sources include leakage of water from contaminated shallow aquifers

${ }^{1}$ Corresponding author: USGS California Water Science Center, 4165 Spruance Rd., Ste. 200, San Diego, CA 92101; randers@usgs.gov

${ }^{2}$ USGS California Water Science Center, 4165 Spruance Rd., Ste. 200, San Diego, CA 92101.

${ }^{3}$ USGS Denver Federal Center, Box 25046, MS 963, BIdg. 21, Denver, CO 80225.

Received June 2012, accepted July 2013.

(C) 2013, National Ground Water Association.

doi: $10.1111 /$ gwat. 12108 through failed well casings, agricultural return flows, saline water entrapped in clay layers, connate saline water from poorly flushed aquifers, and upconing of underlying brines (Jones et al. 1999; Vengosh et al. 2002). The impact of these other sources often is not considered and consequently, the source zones, movement, and composition of saline groundwater may be misinterpreted or not fully understood.

Like other coastal areas throughout the world (Vengosh et al. 1999, 2005; Fakir et al. 2002; Capaccioni et al. 2005; Chen and Jiao 2007) where the presence of saline groundwater degrades the quality of water in aquifers, future development of the local groundwater resources in the San Diego area of southern California is limited by the presence of saline groundwater in some parts of the coastal aquifer (Danskin and Church 2005). Unlike in other areas with significant oil, gas, or water resources, investigations of groundwater in the San Diego area have been sporadic (California Department of Water Resources 1967) and the state of knowledge about this coastal aquifer relies mostly on mapping of surficial geology (Ellis and Lee 1919; Abbott 1999).

Therefore, in contrast to most groundwater studies which start with known subsurface geology and then analyze groundwater quality to better define groundwater flow paths and hydrogeologic units, this study uses 
geochemistry as an aid in the initial mapping of the subsurface. In particular, this study uses a chemical and isotopic approach to determine the sources and movement of saline groundwater in the San Diego coastal aquifer. Chemical and isotopic data were collected from seven multiple-depth monitoring-well sites near the San Diego coastline at discrete intervals to depths of more than $600 \mathrm{~m}$. The groundwater samples were analyzed for major and minor ions; the stable isotopes of hydrogen, oxygen, and strontium; and the radioactive isotopes of tritium and carbon-14. Each chemical and isotopic tracer preserves some aspect of the hydrologic history of the groundwater ranging from the chemical composition of the groundwater (major and minor ions), to the source of water (stable isotopes of oxygen and hydrogen), to the types of rock encountered in the groundwater flow system (strontium isotopes), to time-since-recharge (tritium and carbon-14). No single tracer provides all the needed information to define the source and movement of saline groundwater, but when used together these geochemical tracers can aid local water agencies in mapping the subsurface and constructing a conceptual hydrogeologic framework of a coastal aquifer.

\section{Hydrogeologic Setting}

The study area consists of five major rivers (San Dieguito, San Diego, Sweetwater, Otay, and Tijuana) that start in 2000-m high mountains, flow across the coastal hills and terraces, and empty into the ocean (Figure 1). The area extends from the drainage-basin divide formed by the Laguna Mountains, to the western edge of the continental shelf beneath the Pacific Ocean. The northern and southern boundaries also correspond to drainage-basin divides.

The climate in the coastal San Diego area generally is mild, with temperatures averaging $18{ }^{\circ} \mathrm{C}$ and average annual precipitation ranging from 25 to $33 \mathrm{~cm}$ (Wright and Belitz 2011). What precipitation does fall, mostly as rain and nearly all during the winter months, quickly runs off to the Pacific Ocean. Several small reservoirs in the area capture some local runoff, but they are used primarily to store imported water. On average, San Diego must import nearly $90 \%$ of its water from other areas, specifically northern California and the Colorado River (City of San Diego 2011).

Much of the coastal San Diego area overlies a pullapart structural basin formed by strike-slip faulting, with normal faulting on the lateral margins (Keller and Ward 2001). The major rivers cut obliquely across these tectonically active features, creating narrow valleys that are successively eroded and refilled with sediment in response to uplift and sea-level changes (Hanson et al. 2009).

The largest volume of groundwater recharge within the study area occurs east of a band of metavolcanics that divide the coastal sediment from the higher elevation hard rock (Flint et al. 2012). Although some groundwater is extracted from low-capacity wells in the hard rock, most potable groundwater in the San Diego area is extracted from wells in the coastal sediment. These wells range in depth from about 50 to $250 \mathrm{~m}$, and are believed to extract water from the Pliocene San Diego Formation and overlying Quaternary deposits. Groundwater with a greater salinity is found in some parts of the San Diego Formation and the underlying Eocene sediment; however, the distribution and source of the saline water are not known (Huntley et al. 1998). Similarly, only limited information is available about the areal and vertical distribution of aquifer characteristics. Even the boundaries between the Quaternary deposits and the San Diego Formation, and between the San Diego Formation and underlying older sediment, are uncertain.

\section{Approach}

In 2001, local water agencies and the United States Geological Survey (USGS) began a comprehensive geologic, hydrologic, and geochemical investigation of the groundwater resources in the coastal San Diego area (http://ca.water.usgs.gov/sandiego). An integral part of the investigation was the installation of 11 USGS multipledepth monitoring-well sites, each with as many as 6 monitoring wells, for the collection of groundwater samples from discrete intervals to depths of more than 600 $\mathrm{m}$. The seven USGS multiple-depth monitoring-well sites where water-quality samples were collected for this study are listed in Table S1 (Supporting Information). The locations of these seven multiple-depth monitoring-well sites were chosen to define the hydrogeologic setting of the coastal aquifer (refer to Figure 1). The six domestic wells where groundwater samples were collected are located in the fractured crystalline rock in the eastern part of San Diego County.

\section{Data Collection}

Groundwater samples were collected using a variablespeed submersible Bennett sampling pump (Bennett Sample Pumps, Inc., Amarillo, Texas) and processed in the field following USGS field-sampling procedures (U.S. Geological Survey, variously dated). Water samples were analyzed for major and minor ions at the USGS National Water-Quality Laboratory (NWQL) in Denver, Colorado, using methods described generally by Fishman and Friedman (1989) and Fishman (1993).

Deuterium $\left({ }^{2} \mathrm{H}\right)$ and oxygen-18 $\left({ }^{18} \mathrm{O}\right)$ are stable isotopes that were used in this study to identify different sources of recharge to the coastal aquifer (Clark and Fritz 1997). ${ }^{2} \mathrm{H}$ and ${ }^{18} \mathrm{O}$ values are expressed as $\delta^{2} \mathrm{H}$ and $\delta^{18} \mathrm{O}$ in per mil (\%o) deviation from the ${ }^{2} \mathrm{H} /{ }^{1} \mathrm{H}$ and ${ }^{18} \mathrm{O} /{ }^{16} \mathrm{O}$ ratios in a standard known as the Vienna Standard Mean Ocean Water (VSMOW), which is assigned $\delta^{2} \mathrm{H}$ and $\delta^{18} \mathrm{O}$ values of zero \%o (Gat and Gonfiantini 1981). $\delta^{2} \mathrm{H}$ and $\delta^{18} \mathrm{O}$ samples were analyzed at the USGS Stable Isotope Laboratory in Reston, Virginia, with a precision (two-sigma) of 2 and $0.2 \%$, respectively, using methods described by Epstein and Mayeda (1953), Coplen et al. (1991), and Coplen (1994). 


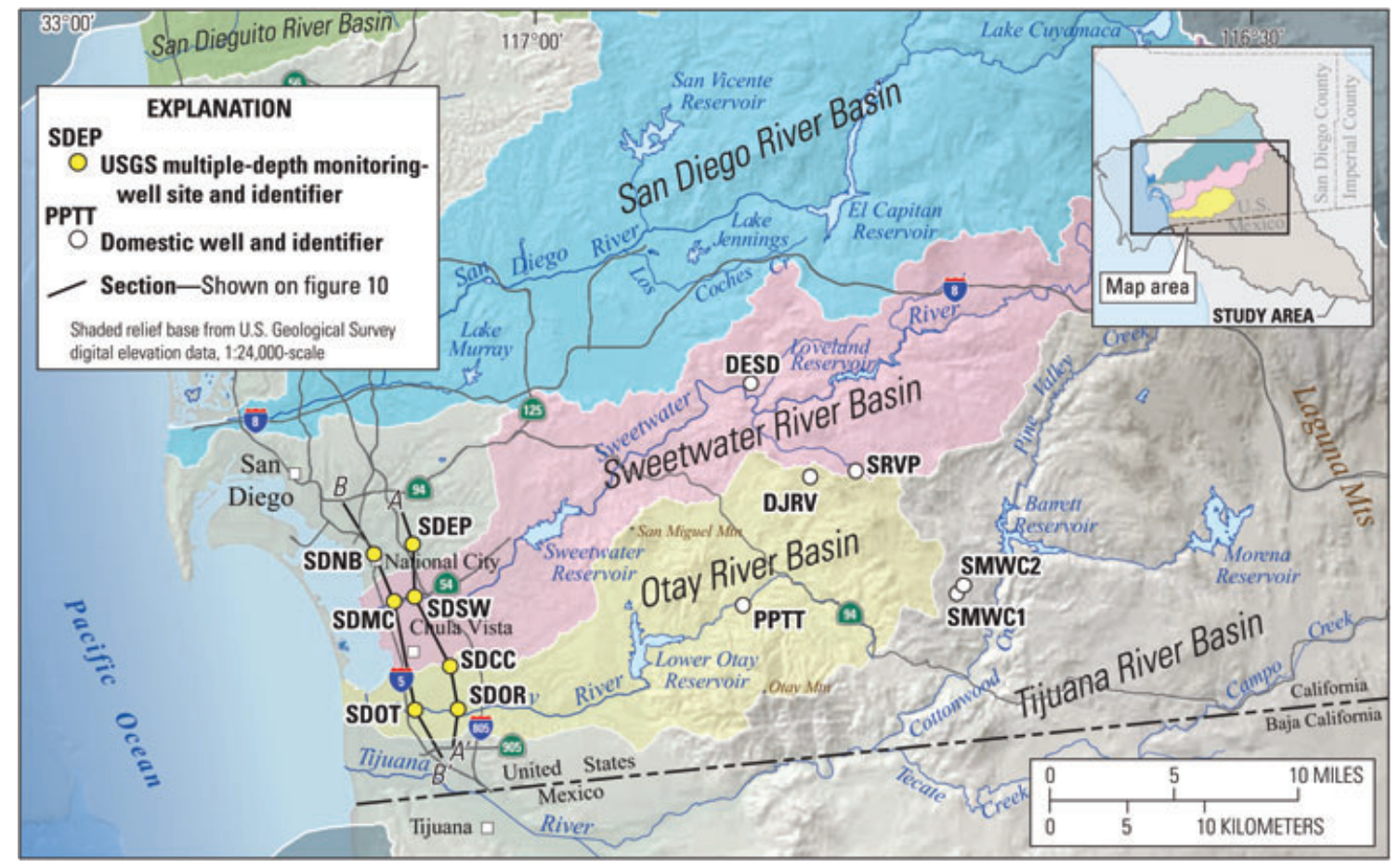

Figure 1. Map showing study area and the location of the five major coastal rivers (San Dieguito, San Diego, Sweetwater, Otay, and Tijuana) in the San Diego area, California.

Strontium ( $\mathrm{Sr}$ ) is an alkaline-earth element with similar geochemical behavior to calcium in natural systems and has four natural stable isotopes: ${ }^{84} \mathrm{Sr},{ }^{86} \mathrm{Sr}$, ${ }^{87} \mathrm{Sr}$, and ${ }^{88} \mathrm{Sr}$ (Shand et al. 2009). Some of the ${ }^{87} \mathrm{Sr}$ have been formed by the beta decay of ${ }^{87} \mathrm{Rb}$ with a half-life of 48.8 billion years. $\mathrm{Sr}$ isotopic fractionation during most geochemical reactions is small, making $\mathrm{Sr}$ concentrations and strontium isotope $\left({ }^{87} \mathrm{Sr} /{ }^{86} \mathrm{Sr}\right)$ ratios particularly useful for detecting mixing among waters of different sources, as well as in characterizing the effects of water-rock interaction (Jørgensen et al. 2008). $\mathrm{Sr}$ and ${ }^{87} \mathrm{Sr} /{ }^{86} \mathrm{Sr}$ analyses were done in the USGS Yucca Mountain Project Branch Strontium Isotope Laboratory (now located in the Crustal Geophysics and Geochemistry Science Center in Denver, Colorado). Sr samples were analyzed using methods described by Garbarino (1999). For ${ }^{87} \mathrm{Sr} /{ }^{86} \mathrm{Sr}$ analyses, samples were evaporated on rhenium (Re) filaments following ion-exchange and analyzed on an upgraded (Spectromat) Finnigan MAT262, thermoionization mass spectrometer (TIMS). For instrument fractionation, $\mathrm{Sr}$ isotope ratios were normalized to an ${ }^{87} \mathrm{Sr} /{ }^{86} \mathrm{Sr}$ value of 0.1194 and ${ }^{87} \mathrm{Sr} /{ }^{86} \mathrm{Sr}$ values were adjusted accordingly by a power law. The average ${ }^{87} \mathrm{Sr} /{ }^{86} \mathrm{Sr}$ value, the NIST standard SRM-987, was 0.710280 during this study with a 2-sigma internal precision of 0.000015 .

Tritium $\left({ }^{3} \mathrm{H}\right)$ is the radioactive isotope of hydrogen; it has a half-life of 12.32 years (Lucas and Unterweger 2000). Because of its short half-life, tritium is useful for identifying water that has been in the hydrologic cycle more or less than about 60 years (Clark and Fritz 1997). Tritium samples were analyzed at the USGS Isotope
Tracers Laboratory in Menlo Park, California, by liquid scintillation after electrolytic enrichment as described by Thatcher et al. (1977). Tritium is reported as an activity (pico-Curies per liter; $\mathrm{pCi} / \mathrm{L}$ ) and related to tritium units (TUs) by the conversion factor: $1 \mathrm{TU}=3.2 \mathrm{pCi} / \mathrm{L}$; each TU equals one ${ }^{3} \mathrm{H}$ atom in $10^{18}$ atoms of hydrogen. The activity of tritium is reported with a two-sigma estimate of precision.

Carbon-14 $\left({ }^{14} \mathrm{C}\right)$, the naturally occurring radioactive isotope of carbon, has a half-life of 5730 years and can be used to determine the age (time since recharge) of groundwater on scales ranging from recent to tens of thousands of years (Clark and Fritz 1997). Carbon-13 and carbon-14 analyses were performed at the Woods Hole Oceanographic Institution, National Ocean Sciences Accelerator Mass Spectrometry Facility using methods described by Karlen et al. (1964), Olsson (1970), Stuiver and Polach (1977), Stuiver (1980), and Beukins (1992). The reference material for carbon-13 is Vienna Pee Dee Belemnite (VPDB), which is assigned a $\delta^{13} \mathrm{C}$ value of 0\%o (Coplen 1994). The activity of carbon-14, expressed as percent modern carbon (pmc), is reported with a onesigma estimate of precision relative to the 1950 National Bureau of Standards oxalic acid standard (Stuiver and Polach 1977; Wigley and Muller 1981).

\section{Results}

\section{Major- and Minor-lon Chemistry}

Chemical data collected from the seven USGS multiple-depth monitoring-well sites and six domestic 
wells in San Diego County, California, are presented in Table S2. The major-ion chemistry of groundwater samples in the coastal San Diego area is shown by the trilinear diagram in Figure 2. A trilinear diagram depicts the relative proportions of major ions on a chargeequivalent basis for comparison and classification of water samples independent of total analyte concentrations (Hem 1985). On the basis of the major-ion data, the chemical composition of groundwater samples from the seven multiple-depth monitoring-well sites and six domestic wells can be classified into three groups.

Relative proportions of major ions in group 1 indicate the chemical composition can be classified as sodium-calcium-chloride-sulfate $\left(\mathrm{Na}-\mathrm{Ca}-\mathrm{Cl}-\mathrm{SO}_{4}\right)$ type water. Group 1 is represented by 14 monitoring wells (SDCC6; SDEP3-5; SDMC5; SDNB2; SDOR3, 5; SDOT3-5; SDSW4-6; Table S2). The chemical composition of group 2 is classified as $\mathrm{Na}-\mathrm{Cl}$ type water and is represented by 12 monitoring wells (SDCC1-5; SDEP1, 2; SDOR1, 2; SDSW1-3; Table S2). Samples which plot in the bottom-right portion of the diamond in Figure 2 are considered a subset of group 2 and are represented by two monitoring wells (SDOT1, 2; Table S2). The chemical composition of group 3 can be classified as primarily a $\mathrm{Na}-\mathrm{Ca}-\mathrm{Cl}$ type water and is represented by eight monitoring wells (SDMC1-4; SDNB1, 3-5; Table S2). The relative proportions of major ions in group 3 resemble the major-ion composition of sea water (Hem 1985). The six domestic well samples located in the eastern part of the study area have compositions most similar to group 1, but have slightly greater proportions of $\mathrm{Ca}$ and $\mathrm{HCO}_{3}$.

The chloride/bromide mass $(\mathrm{Cl} / \mathrm{Br})$ ratio in sea water is about 285 so most natural waters have a ratio close to this value; typical $\mathrm{Cl} / \mathrm{Br}$ ratios in coastal groundwater are close to 290 (Davis et al. 1998). Although $\mathrm{Cl}$ and $\mathrm{Br}$ are highly soluble, and both halides are typically conservative during subsurface transport (Jones et al. 1999), Br is slightly more soluble than $\mathrm{Cl}$. As a result, during the evaporation process the insoluble residue (evaporite salt) is preferentially enriched in $\mathrm{Cl}$ and the residual solution is enriched in $\mathrm{Br}$. The net result is that the $\mathrm{Cl} / \mathrm{Br}$ ratio in groundwater samples affected by dissolution of halite in salt beds can be higher than 4000 (Davis et al. 1998). The average $\mathrm{Cl} / \mathrm{Br}$ ratio for groundwater samples in groups 1 and 2 is about 294 (s.d.=22.8) (Figure 3; Table S2). The $\mathrm{Cl} / \mathrm{Br}$ ratio for groundwater samples close to the sea water value indicates that chloride concentrations greater than sea water (SDNB3, 4) likely result from evaporated sea water rather than dissolution of halites (Davis et al. 1998; Faye et al. 2005).

\section{Stable Isotopes}

The isotopic data collected from the seven USGS multiple-depth monitoring-well sites and six domestic

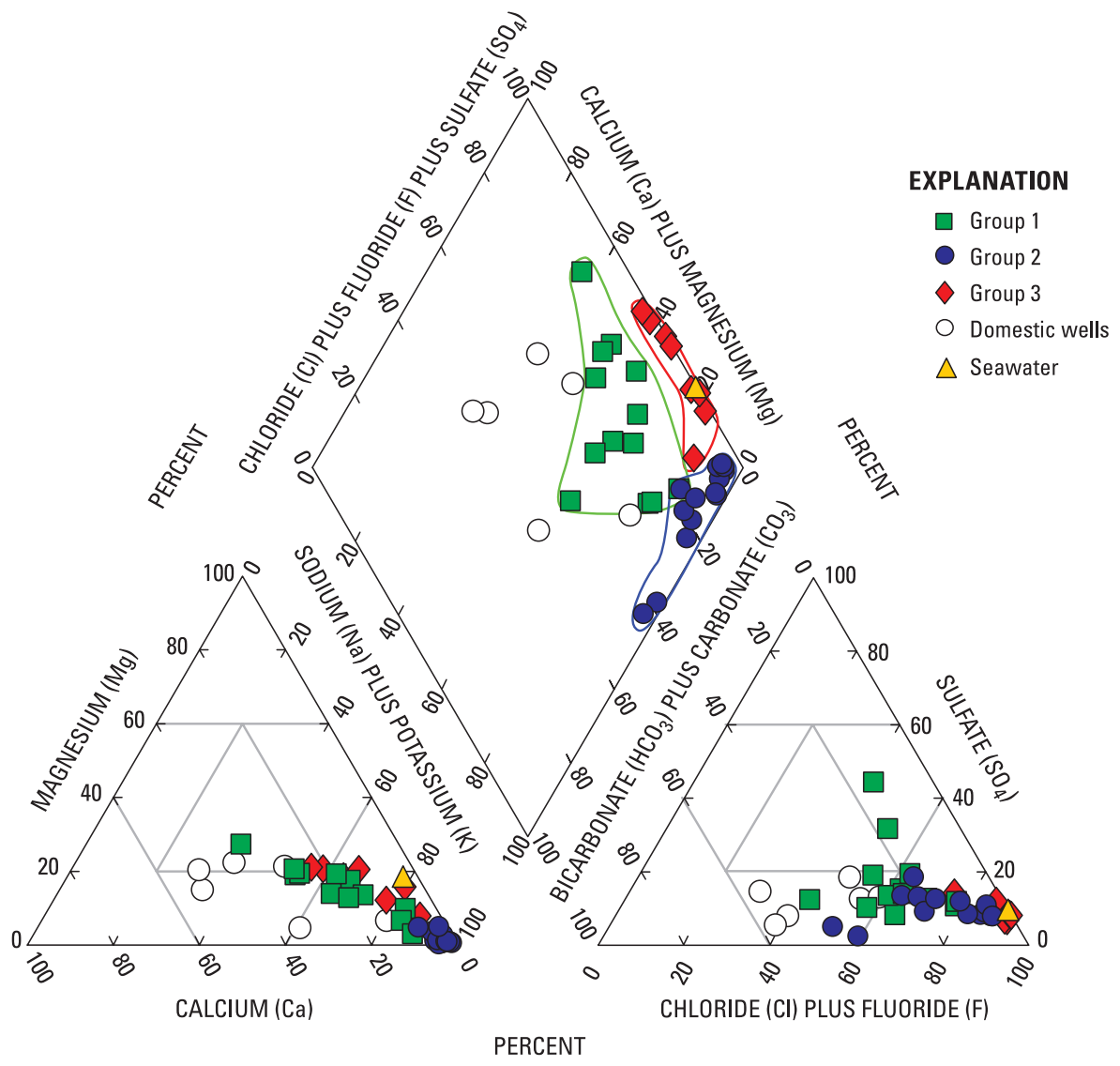

Figure 2. Trilinear diagram showing the relative proportions of major ions for three major groups of groundwater samples from seven multiple-depth monitoring-well sites and six domestic wells in San Diego County, California. 


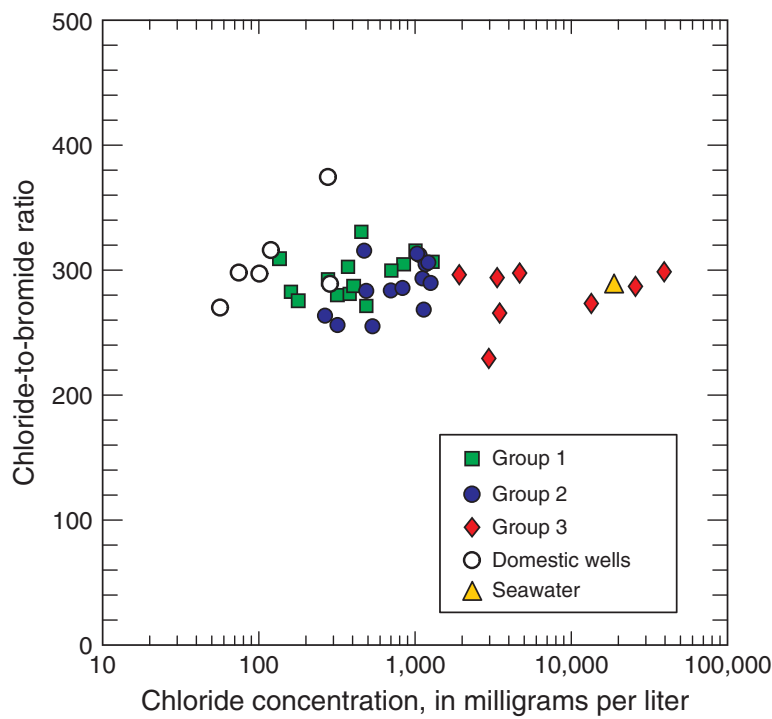

Figure 3. $\mathrm{Cl} / \mathrm{Br}$ ratios versus $\mathrm{Cl}$ concentrations for three major groups of groundwater samples from seven multipledepth monitoring-well sites and six domestic wells in San Diego County, California.

wells in San Diego County, California, are presented in Table S2. Groundwater samples collected from the San Diego area have $\delta^{2} \mathrm{H}$ and $\delta^{18} \mathrm{O}$ values from $-47.7 \%$ o to $-12.8 \%$ and from $-7.2 \%$ to $-1.2 \%$, respectively, and indicate at least three distinct sources of recharge to the coastal aquifer (Figure 4; Table S3). These sources are distinguishable (Williams and Rodoni 1997) by: (1) intermediate isotopic values which plot along the Global Meteoric Water Line (GMWL) and are characteristic of recharge originating in the coastal sediment (group 1 ); (2) depleted (most negative) $\delta^{2} \mathrm{H}$ and $\delta^{18} \mathrm{O}$ isotopic values which plot along the GMWL and reflect recharge originating in the fractured crystalline rock more than 20 $\mathrm{km}$ east and upgradient from the coastline (group 2 and most domestic wells); and (3) isotopically enriched (least negative) $\delta^{2} \mathrm{H}$ and $\delta^{18} \mathrm{O}$ values which plot along a sea water mixing line (SML) and reflect variable amounts of mixing of sea water with recharge from coastal precipitation (group 1) or higher-elevation precipitation (group 2). Other water samples which plot to the right of the GMWL (SDCC6) may have been affected by evaporation of the water prior to infiltration (Izbicki et al. 2005).

\section{${ }^{87} \mathrm{Sr} /{ }^{86} \mathrm{Sr}$}

For San Diego groundwater samples, $\mathrm{Sr}$ concentrations and ${ }^{87} \mathrm{Sr} /{ }^{86} \mathrm{Sr}$ ratios ranged from $0.02 \mathrm{mg} / \mathrm{L}$ (SRVP) to $18.9 \mathrm{mg} / \mathrm{L}$ (SDNB1) and from 0.70511 (SRVP) to 0.70898 (SDNB4), respectively (Tables S2 and S3). The lowest $\mathrm{Sr}$ concentrations correspond to the lowest ${ }^{87} \mathrm{Sr} /{ }^{86} \mathrm{Sr}$ ratios which are found in groundwater samples collected from the six domestic wells located in the fractured crystalline rock in the eastern part of the study area (Figure 5). In contrast, the highest $\mathrm{Sr}$ concentration corresponds to the highest ${ }^{87} \mathrm{Sr} /{ }^{86} \mathrm{Sr}$ ratio and is found in a group 3 well (SDNB4).

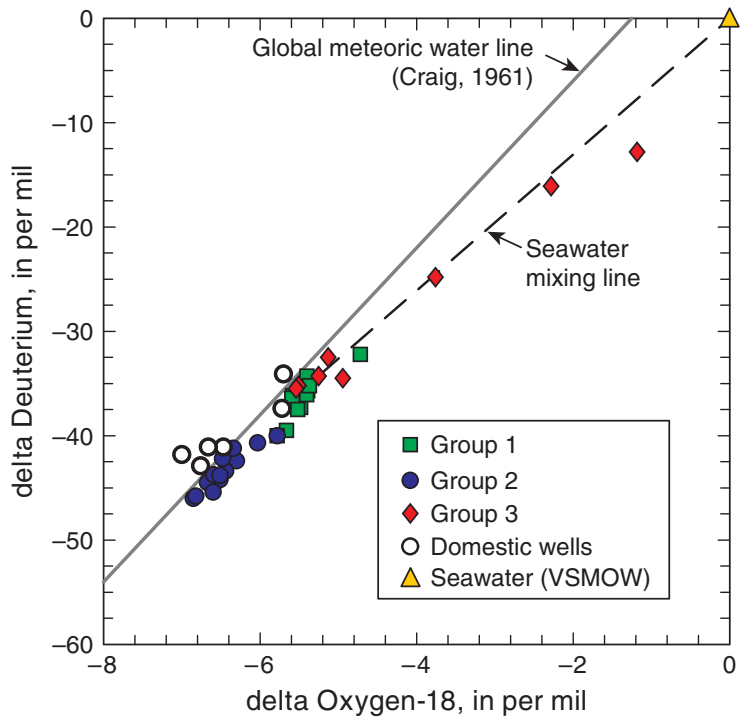

Figure 4. $\delta^{2} \mathrm{H}$ versus $\delta^{18} \mathrm{O}$ values for three major groups of groundwater samples from seven multiple-depth monitoringwell sites and six domestic wells in San Diego County, California.

This apparent correlation between $\mathrm{Sr}$ concentrations and ${ }^{87} \mathrm{Sr} /{ }^{86} \mathrm{Sr}$ ratios in groundwater and sea water might be explained by mixing of groundwater with sea water along a single flow path originating in the fractured crystalline rock and terminating at the coast (Vengosh et al. 2002; Jørgensen et al. 2008). However, the lack of a direct correlation between the $\mathrm{Sr}$ concentrations for water samples in groups 1 and 2 and their corresponding ${ }^{87} \mathrm{Sr} /{ }^{86} \mathrm{Sr}$ ratios (Figure 5) requires more complex processes than mixing of two end members. Other explanations rely on the isotopic composition and concentration of $\mathrm{Sr}$ in the rocks and minerals that the groundwater encounters along the flow path (Shand et al. 2009), the ${ }^{87} \mathrm{Sr} /{ }^{86} \mathrm{Sr}$ ratio of sea water at the time of deposition (Prokoph et al. 2008), and the contribution of a third source of water to the mixing zone between fresh groundwater and sea water in the coastal aquifer (Jørgensen et al. 2008).

\section{Groundwater Ages}

Each groundwater sample collected for this study was assigned an age classification based on the following criteria: (1) ${ }^{3} \mathrm{H}$ activity greater than $1 \mathrm{TU}$ and ${ }^{14} \mathrm{C}$ activity greater than 90 pmc was designated as modern; (2) ${ }^{3} \mathrm{H}$ activity less than $1 \mathrm{TU}$ and ${ }^{14} \mathrm{C}$ activity less than $90 \mathrm{pmc}$ was designated as premodern or recharged before 1953; and (3) samples having components of both premodern and modern water were designated as mixed (Table S2) (Wright and Belitz 2011).

Modern water occurred in two domestic wells in the eastern part of the study area (DESD; SMWC2) and the shallowest monitoring well at one site (SDSW6). Mixed water occurred in three monitoring wells (SDMC5, SDCC6, and SDOT5). All other water samples collected for this study, excluding one which was not measured for tritium (SDNB1) and one which was not measured 


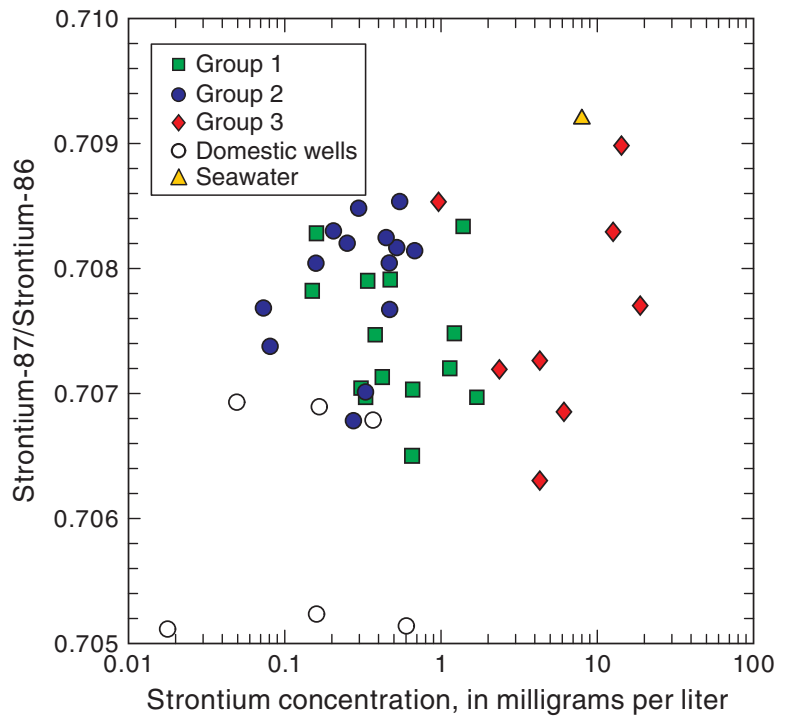

Figure 5. ${ }^{87} \mathrm{Sr} /{ }^{86} \mathrm{Sr}$ ratios versus $\mathrm{Sr}$ concentrations for three major groups of groundwater samples from seven multipledepth monitoring-well sites and six domestic wells in San Diego County, California.

for ${ }^{14} \mathrm{C}$ activity (SDNB5), were classified as premodern. The presence of modern water in only the shallowest monitoring wells and the eastern part of the study area indicates very little modern $(<60$ years old) groundwater is present in the coastal aquifer. Instead, the low ${ }^{14} \mathrm{C}$ activities indicate most of the groundwater in the coastal aquifer was recharged many thousands of years ago.

A more accurate determination of the ages of groundwater from wells in the coastal San Diego area relies on two major assumptions: (1) the initial ${ }^{14} \mathrm{C}$ activity is known and (2) the subsurface behaves as a closed system without any gains or losses, other than through radioactive decay (Clark and Fritz 1997). In reality, ${ }^{14} \mathrm{C}$ that has been isolated from the atmosphere is seldom affected by just radioactive decay. Carbonate reactions along a groundwater flow path can change the amount of ${ }^{14} \mathrm{C}$ by either the addition of dissolved inorganic carbon (DIC) that results from dissolution of calcite or dolomite, which gives the appearance of older water, or by the removal of DIC that contains ${ }^{14} \mathrm{C}$, which gives the appearance of younger water. To obtain a "true" age of groundwater (the time elapsed between recharge and discharge) based on ${ }^{14} \mathrm{C}$, measured ${ }^{14} \mathrm{C}$ activities need to be corrected by using geochemical modeling and carbon$13\left(\delta^{13} \mathrm{C}\right)$ data.

The $\delta^{13} \mathrm{C}$ values for groundwater samples range from $-18.9 \%$ o to $-6.9 \%$ o, suggesting that carbonate reactions probably occur. The absence of a consistent inverse relationship between $\delta^{13} \mathrm{C}$ values and ${ }^{14} \mathrm{C}$ activities, however, suggests that corrections of ${ }^{14} \mathrm{C}$ activities would be problematic (Figure 6; Table S3). Therefore, ${ }^{14} \mathrm{C}$ activities were retained for comparing the relative ages of groundwater in the coastal San Diego area. ${ }^{14} \mathrm{C}$ activities for group 2 wells range from 0.4 to $12.4 \mathrm{pmc}$ and reflect the oldest groundwater. Groundwater samples from group

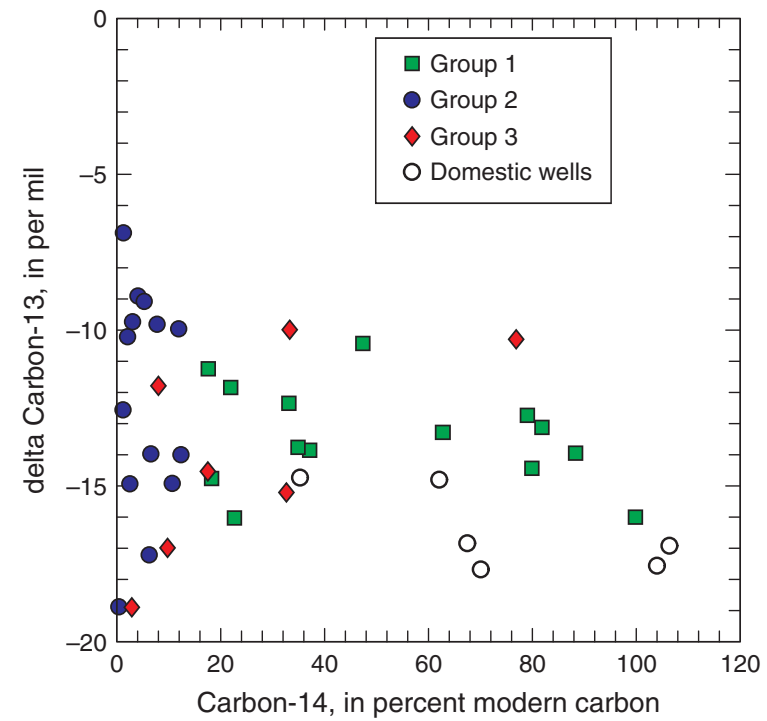

Figure 6. $\delta^{13} \mathrm{C}$ values versus ${ }^{14} \mathrm{C}$ activities for three major groups of groundwater samples from seven multiple-depth monitoring-well sites and six domestic wells in San Diego County, California.

1 wells have higher ${ }^{14} \mathrm{C}$ activities ranging from 17.6 to 99.8 pmc. Group 3 wells have a range of ${ }^{14} \mathrm{C}$ activities from 2.9 to 76.9 pmc.

\section{Discussion}

The use of mixing models to better understand the various processes occurring in a coastal aquifer relies on measured water compositions and concentrations calculated for conservative mixing of freshwater and sea water. In such models, waters plotting above a mixing line indicate the groundwater has been enriched for an individual cation or anion, whereas waters that plot below the mixing line indicate depletion compared to conservative mixing (Ravenscroft and McArthur 2004; Andersen et al. 2005).

A simple binary mixing line between sea water and the average $\mathrm{Na}, \mathrm{Ca}$, and $\mathrm{Cl}$ concentrations of the six domestic well samples $(98.3 \mathrm{mg} / \mathrm{L} \mathrm{Na}, 71.1 \mathrm{mg} / \mathrm{L}$ $\mathrm{Ca}, 152.5 \mathrm{mg} / \mathrm{L} \mathrm{Cl}$ ), along with the measured water composition of the groundwater samples from the seven multiple-depth monitoring well sites, indicate that $\mathrm{Na}$ is only slightly enriched or depleted relative to diluted sea water in all groups (Figure 7a). In contrast, all groundwater samples from group 2 wells are depleted in $\mathrm{Ca}$, groundwater samples from group 3 wells are slightly enriched in $\mathrm{Ca}$, and group 1 wells contain groundwater both enriched and depleted in $\mathrm{Ca}$ (Figure 7b). The enrichment and depletion of these species in the groundwater allow the influence of residual salinity to be detached from the influence of the exchange and sorption reactions (Ravenscroft and McArthur 2004).

The model by Appelo and Postma (2005) for the process of ion exchange resulting from interactions between sea water and fresh groundwater is applicable for 
(a)

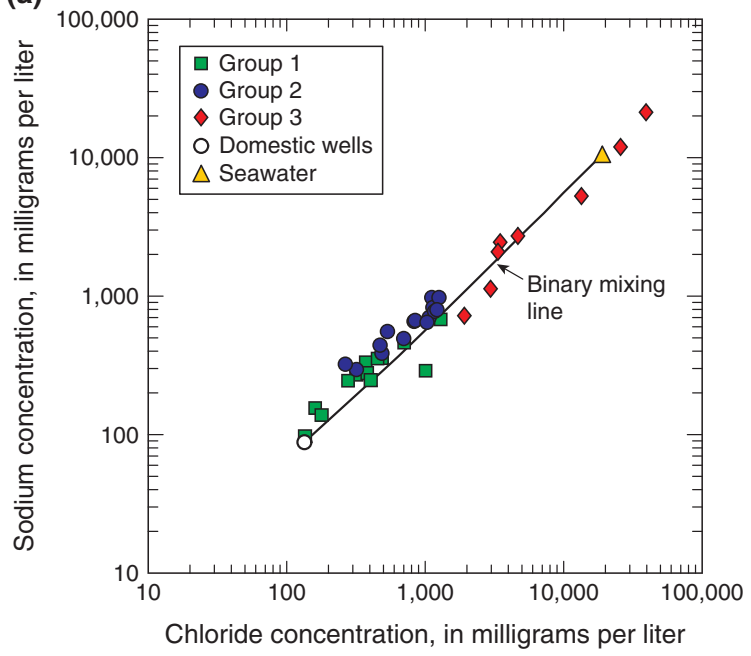

(b)

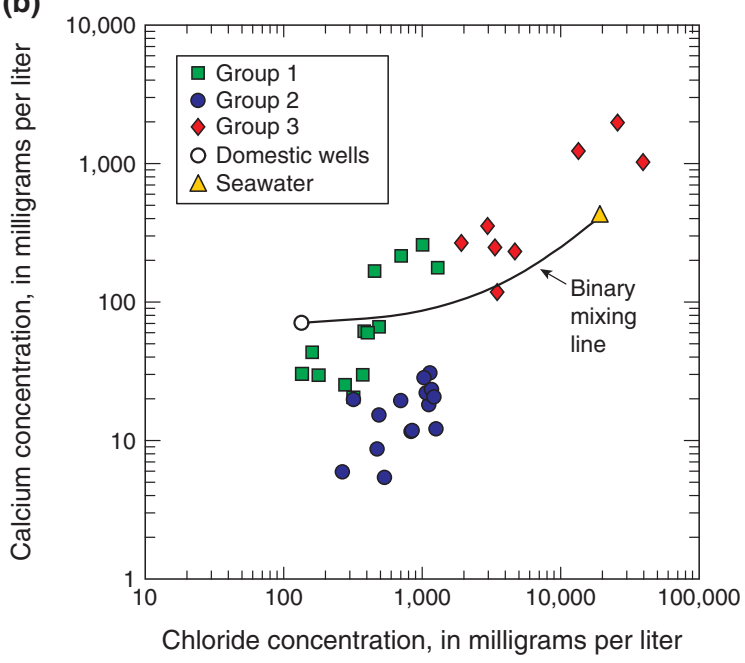

Figure 7. Na and $\mathrm{Ca}$ concentrations versus $\mathrm{Cl}$ concentrations for three major groups of groundwater samples from seven multiple-depth monitoring-well sites in the San Diego area: (a) Na concentrations; (b) Ca concentrations. Also shown is the average concentration for the six domestic well samples.

understanding the processes responsible for the presence of saline groundwater in the San Diego coastal aquifer. In sea water, $\mathrm{Na}$ and $\mathrm{Cl}$ are the dominant ions. When sea water intrudes into a freshwater aquifer where $\mathrm{Ca}$ is the dominant absorbed cation, $\mathrm{Na}$ is taken up by the exchanger, while $\mathrm{Ca}$ is released:

$$
\mathrm{Na}^{+}+1 / 2 \mathrm{Ca}-X_{2} \rightarrow \mathrm{Na}-X+1 / 2 \mathrm{Ca}^{2+}
$$

where $X$ indicates the soil exchanger. In this case, the dominant anion $\mathrm{Cl}$ remains the same, a depletion of $\mathrm{Na}$ and an enrichment of $\mathrm{Ca}$ in groundwater relative to sea water occur, and the sodium-to-calcium mass $(\mathrm{Na} / \mathrm{Ca})$ ratio decreases from the $\mathrm{Na} / \mathrm{Ca}$ ratio for sea water (25.6).

The reverse process takes place when fresh groundwater flushes a previously saline aquifer:

$$
1 / 2 \mathrm{Ca}^{2+}+\mathrm{Na}-X \rightarrow 1 / 2 \mathrm{Ca}-X_{2}+\mathrm{Na}^{+} .
$$

The sediment now absorbs $\mathrm{Ca}$ while $\mathrm{Na}$ is released, an enrichment of $\mathrm{Na}$ and a depletion of $\mathrm{Ca}$ in groundwater relative to diluted sea water occur, and the $\mathrm{Na} / \mathrm{Ca}$ ratio exceeds the sea water $\mathrm{Na} / \mathrm{Ca}$ ratio.

\section{Geochemical Tracers of Saline Groundwater}

Geochemical tracers $(\mathrm{Na} / \mathrm{Ca}$ ratios, $\mathrm{Cl}$ concentrations, $\delta^{18} \mathrm{O}$ values, ${ }^{87} \mathrm{Sr} /{ }^{86} \mathrm{Sr}$ ratios, and ${ }^{14} \mathrm{C}$ activities) aid in defining the source and movement of saline groundwater in the coastal San Diego area (Tables S2 and S3). Groundwater from group 1 wells is characterized by low $\mathrm{Na} / \mathrm{Ca}$ ratios with low to intermediate $\mathrm{Cl}$ concentrations, intermediate $\delta^{18} \mathrm{O}$ values, ${ }^{87} \mathrm{Sr} /{ }^{86} \mathrm{Sr}$ ratios between 0.7070 and 0.7083 , and relatively high ${ }^{14} \mathrm{C}$ activities (Figure 8a to $8 \mathrm{~d}$ ). Groundwater from group 1 wells is considered to be the most representative of the potable groundwater in the San Diego area, much of which is believed to be extracted from the San Diego Formation. The chemical composition of the groundwater from group 1 wells reflects slight enrichment of $\mathrm{Ca}$ owing to dissolution of readily soluble minerals such as calcite near the source of recharge (youngest groundwater) or slight depletion of $\mathrm{Ca}$ as aluminosilicate minerals are weathered and (or) calcium is exchanged for sodium on clay minerals that are present along the groundwater flow path (Ravenscroft and McArthur 2004).

In contrast, the chemical and isotopic composition of groundwater from group 2 wells is characterized by high $\mathrm{Na} / \mathrm{Ca}$ ratios, intermediate $\mathrm{Cl}$ concentrations, depleted $\delta^{18} \mathrm{O}$ values, ${ }^{87} \mathrm{Sr} /{ }^{86} \mathrm{Sr}$ ratios between 0.7068 and 0.7085 , and the lowest ${ }^{14} \mathrm{C}$ activities in the coastal aquifer (Figure 8a to 8d). One explanation for the high $\mathrm{Na} / \mathrm{Ca}$ ratios in group 2 groundwater is a depletion of $\mathrm{Ca}$ due to a decrease in the solubility of calcium carbonate as a consequence of microbial sulfate reduction (Andersen et al. 2005). Some group 2 samples containing low sulfate concentrations appear to be influenced by sulfate reduction, although this process is limited to groundwater samples from two wells (SDOT1, 2) and is not widespread in the coastal aquifer (refer to Figure 2). The more plausible explanation is that the high $\mathrm{Na} / \mathrm{Ca}$ ratios reflect a depletion of $\mathrm{Ca}$ as a result of "freshening" of a previously saline aquifer by the reverse ion-exchange process depicted in Equation 2 (Appelo and Postma 2005; Capaccioni et al. 2005; Russak and Sivan 2010). Because reverse exchange of $\mathrm{Ca}$ should not affect the ${ }^{87} \mathrm{Sr} /{ }^{86} \mathrm{Sr}$ ratios, the maximum ${ }^{87} \mathrm{Sr} /{ }^{86} \mathrm{Sr}$ ratios of group 2 groundwater may reflect the ${ }^{87} \mathrm{Sr} /{ }^{86} \mathrm{Sr}$ ratio of sea water at about the time of deposition of the geologic formation (Prokoph et al. 2008) and the smaller values reflect variable amounts of mixing of modern water with ancient water (Figure 8c).

The group 3 samples have $\mathrm{Na} / \mathrm{Ca}$ ratios less than the sea water $\mathrm{Na} / \mathrm{Ca}$ ratio resulting from the ion-exchange process depicted by Equation 1, consistent with sea water intrusion as the source of saline groundwater to these wells (Appelo and Postma 2005; Chen and Jiao 2007). These groundwaters are characterized by the highest $\mathrm{Cl}$ concentrations with a few samples exceeding the $\mathrm{Cl}$ 

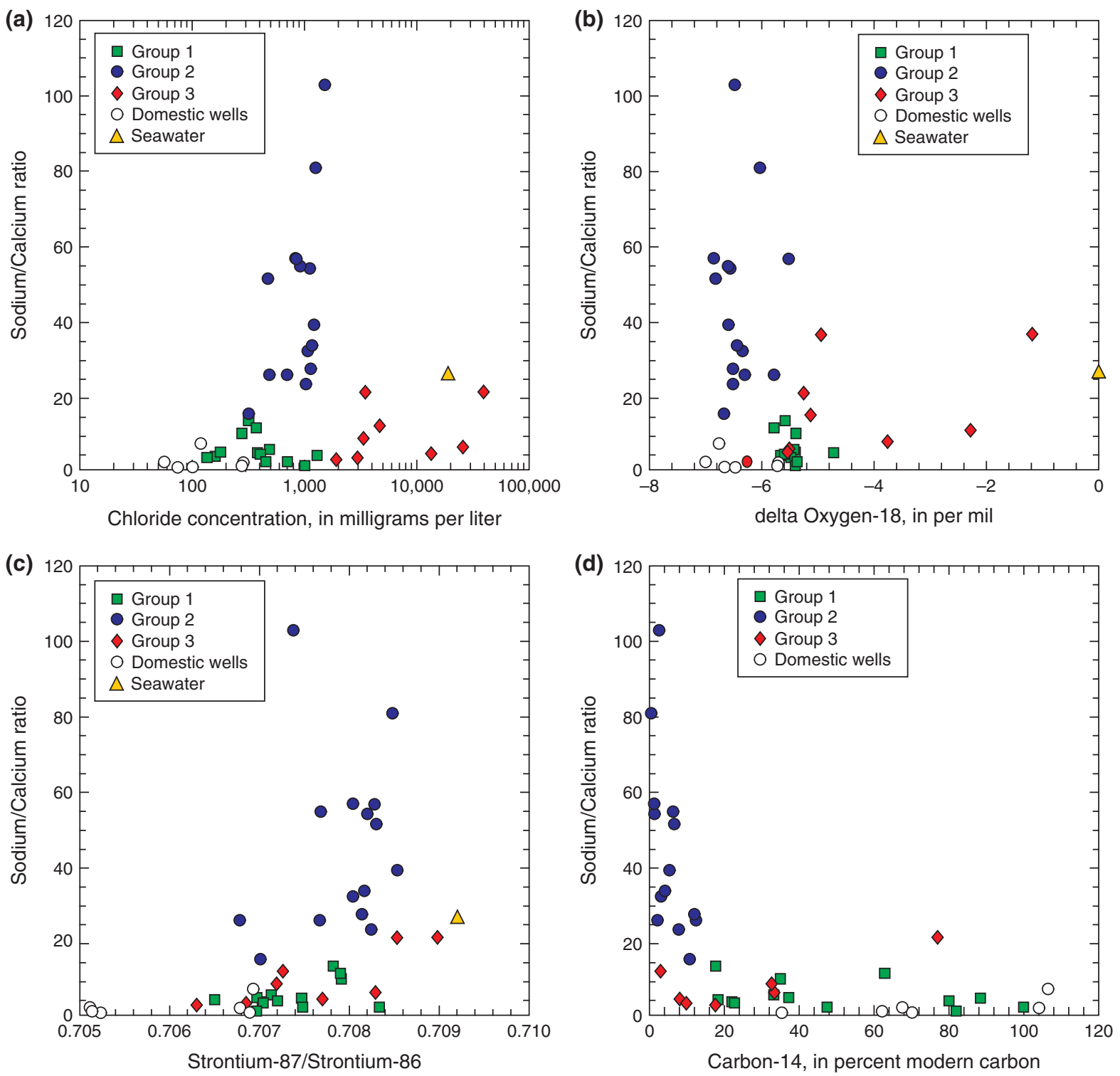

Figure 8. $\mathrm{Na} / \mathrm{Ca}$ ratios for three major groups of groundwater samples from seven multiple-depth monitoring-well sites in the San Diego area versus: (a) $\mathrm{Cl}$ concentrations; (b) $\delta^{18} \mathrm{O}$ values; (c) ${ }^{87} \mathrm{Sr} /{ }^{86} \mathrm{Sr}$ ratios; and (d) ${ }^{14} \mathrm{C}$ activities.

concentration of sea water, enriched $\delta^{18} \mathrm{O}$ values approaching $0.0 \%$ and plotting on a SML reflecting variable amounts of mixing of sea water with recharged groundwater, ${ }^{87} \mathrm{Sr} /{ }^{86} \mathrm{Sr}$ ratios approaching the ${ }^{87} \mathrm{Sr} /{ }^{86} \mathrm{Sr}$ ratio of modern sea water $(0.7092)$, and a range of ${ }^{14} \mathrm{C}$ activities (Figure $8 \mathrm{a}$ to $8 \mathrm{~d}$ ). The low ${ }^{14} \mathrm{C}$ activity in one well (SDNB1; Table S3) located along the coast suggests that this is ancient sea water intrusion, not modern.

\section{Geochemical Differences with Depth}

The relationship between well depth and $\mathrm{Cl}$ concentrations, $\delta^{18} \mathrm{O}$ values, ${ }^{87} \mathrm{Sr} /{ }^{86} \mathrm{Sr}$ ratios, and ${ }^{14} \mathrm{C}$ activities for the three groups indicates different sources of recharge and vertically different flow paths in the coastal San Diego aquifer (Figure 9a to 9d).

The lowest $\mathrm{Cl}$ concentrations are at depths between about 150 and $250 \mathrm{~m}$ (Figure 9a). The $\mathrm{Cl}$ concentrations increase at shallower depths for groups 1 and 2, and increase at greater depths for group 2. The greatest $\mathrm{Cl}$ concentrations occur in group 3 at all depths and delineate zones of sea water intrusion within the coastal aquifer.

The relationship between well depth and $\delta^{18} \mathrm{O}$ values indicates that groundwater recharged from precipitation flows through two different parts of the coastal aquifer (Figure $9 \mathrm{~b}$ ). The intermediate $\delta^{18} \mathrm{O}$ values of group 1 are characteristic of precipitation near the coast, which appears to be the source of recharge to the shallower part of the coastal aquifer. The depleted $\delta^{18} \mathrm{O}$ values of group 2 in the deeper part of the coastal aquifer are characteristic of recharge originating in the fractured crystalline rock more than $20 \mathrm{~km}$ east and upgradient from the coastline (Williams and Rodoni 1997). In addition, the depleted $\delta^{18} \mathrm{O}$ values and high $\mathrm{Na} / \mathrm{Ca}$ ratios indicate that "freshening" of the deeper part of the coastal aquifer 

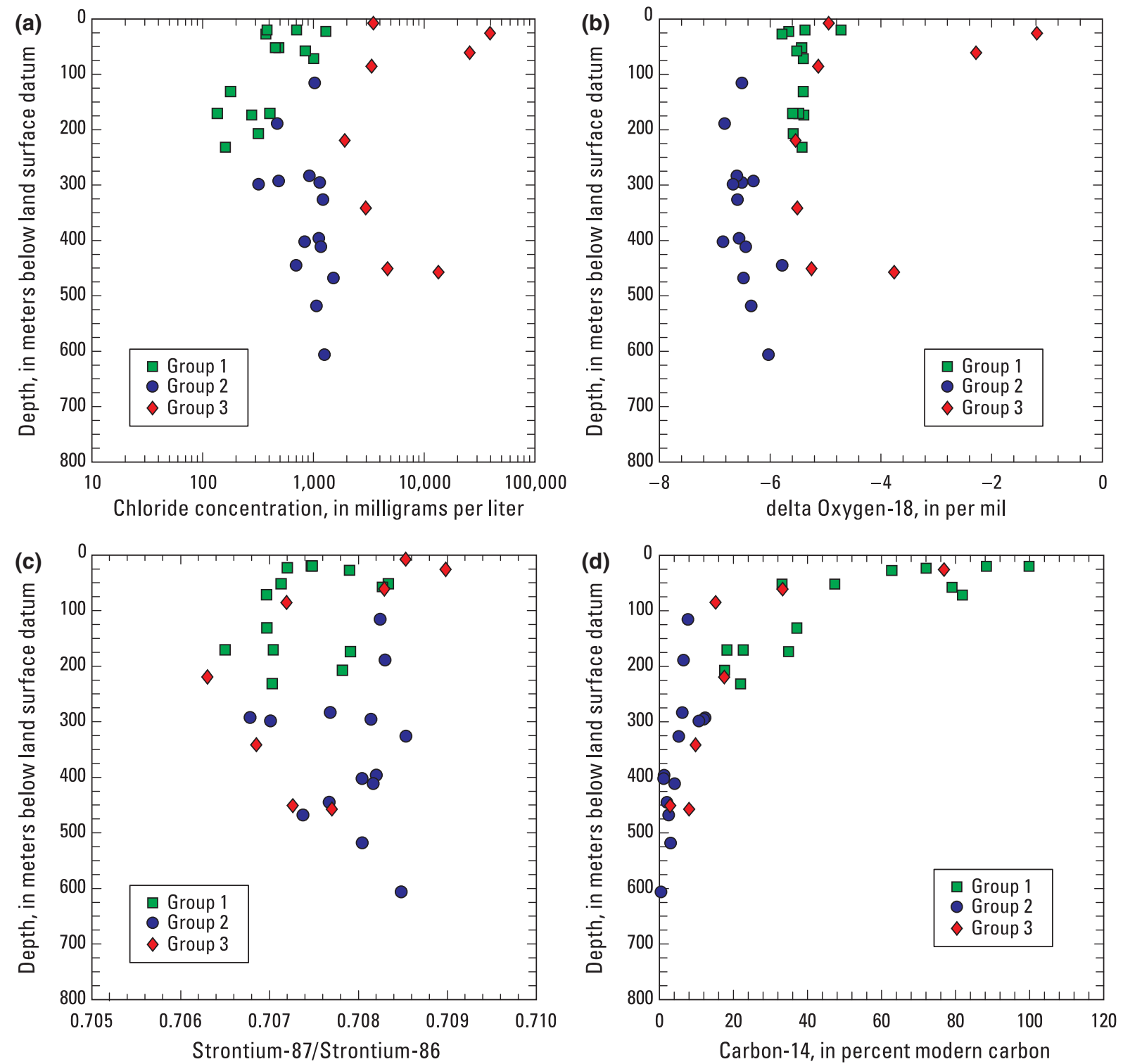

Figure 9. Depths for three major groups of groundwater samples from seven multiple-depth monitoring-well sites in San Diego County, California, versus: (a) Cl concentrations; (b) $\delta^{18} \mathrm{O}$ values; (c) ${ }^{87} \mathrm{Sr} /{ }^{86} \mathrm{Sr}$ isotope ratios; and (d) ${ }^{14} \mathrm{C}$ activities.

continues to occur, long after sea water has been replaced by the distant recharge.

Two distinct flow paths are evident from the relation between well depth and ${ }^{87} \mathrm{Sr} /{ }^{86} \mathrm{Sr}$ isotope ratios (Figure 9c). One flow path is characterized by ${ }^{87} \mathrm{Sr} /{ }^{86} \mathrm{Sr}$ ratios between about 0.7065 and 0.7075 and reflects the range of isotopic compositions of $\mathrm{Sr}$ in the rocks and minerals that are encountered by groundwater that flows through the shallower part of the coastal aquifer. In contrast, the second flow path is characterized by ${ }^{87} \mathrm{Sr} /{ }^{86} \mathrm{Sr}$ ratios between about 0.7075 and 0.7085 and reflects groundwater which encounters different geologic formations as it flows through the deeper part of the coastal aquifer. Group 2 groundwater (SDEP2; SDSW3) in the shallower flow path and group 1 groundwater (SDCC6; SDNB2; SDOR3, 5; SDSW5) in the deeper flow path reflect the complex geologic structure of the pull-apart basin in the coastal San Diego area.

Groundwater samples from group 1 wells corresponding to shallower depths have ${ }^{14} \mathrm{C}$ activities ranging from 17.6 to $99.8 \mathrm{pmc}$, which implies relatively younger water than group 2 and most group 3 samples (Figure 9d). ${ }^{14} \mathrm{C}$ activities for group 2 wells range from 0.4 to $12.4 \mathrm{pmc}$ and suggest the oldest groundwater travels many kilometers before entering the narrow coastal aquifer. In addition, low ${ }^{14} \mathrm{C}$ activities and the high $\mathrm{Na} / \mathrm{Ca}$ ratios suggest that "freshening" of the deeper part of the coastal aquifer has been occurring for a long time.

The notable exceptions are two group 2 wells (SDCC4, 5) which are shallower than $200 \mathrm{~m}$ with ${ }^{14} \mathrm{C}$ activities less than 8 pmc. One possible explanation for these lower ${ }^{14} \mathrm{C}$ activities at shallower depths is normal faulting along the eastern margin of the pull-apart basin, 
(a)
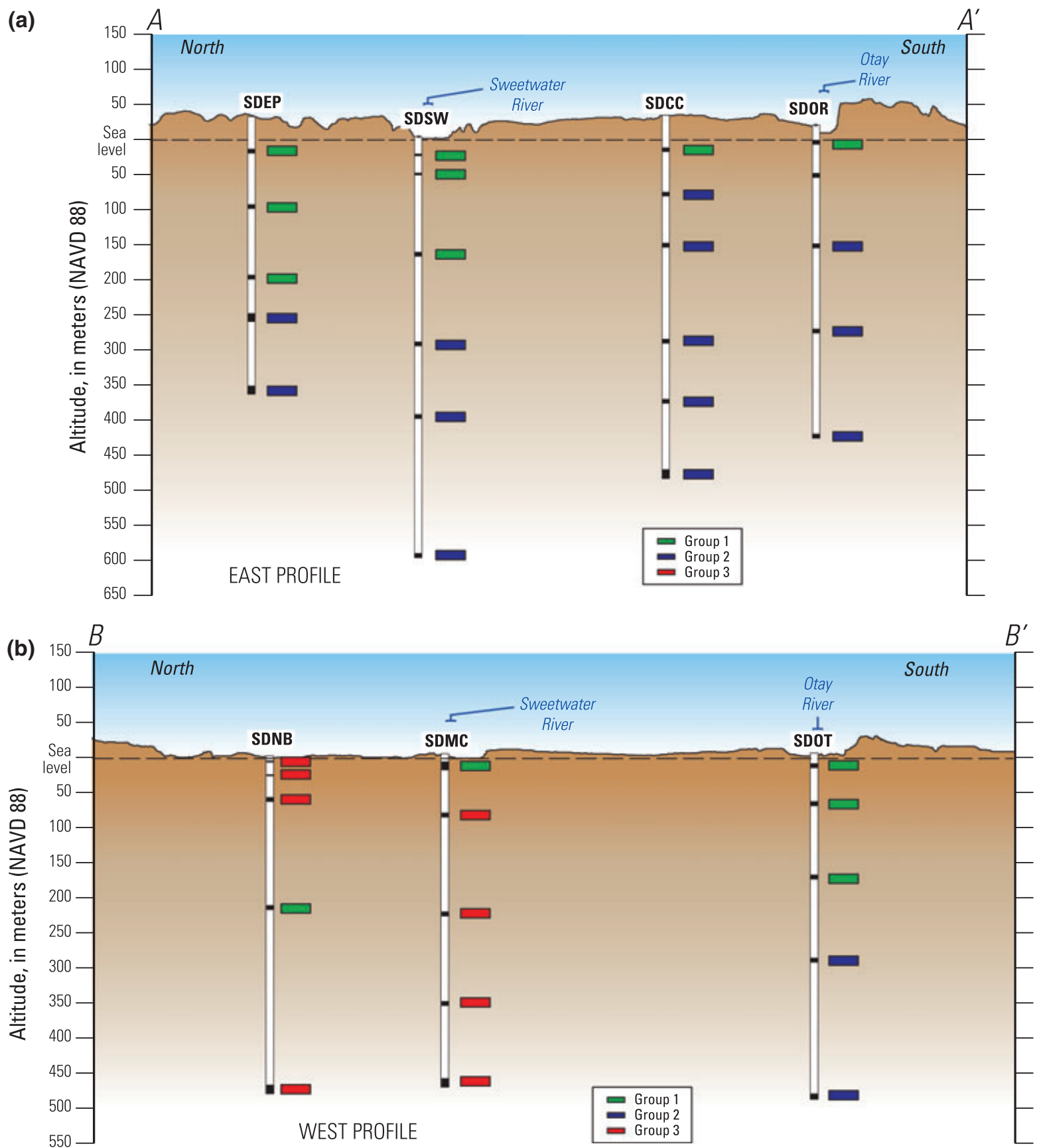

Figure 10. Distribution of three major groups of groundwater samples along sections $A$ to $A^{\prime}$ and $B$ to $B^{\prime}$ shown in Figure 1 , San Diego County, California.

which would allow deep groundwater flowing from the east to enter shallower sediment on the west. Group 3 wells, which have the highest $\mathrm{Cl}$ concentrations in the San Diego area, are found at various depths and have a range of ${ }^{14} \mathrm{C}$ activities from 2.9 to 76.9 pmc.

\section{Geochemical Mapping of the Subsurface}

Two northwest-to-southeast trending sections (Figure 10a and 10b) are used to show the spatial distribution of the three geochemical groups in the San Diego coastal aquifer and to illustrate how the geochemical approach used in this study can aid in mapping the incompletely characterized subsurface. One section is located along the eastern edge of the coastal aquifer $\left(\mathrm{AA}^{\prime}\right)$, and the other section is located along the San Diego Bay $\left(\mathrm{BB}^{\prime}\right)$ (refer to Figure 1).

The eastern section $\mathrm{AA}^{\prime}$ shows group 1 groundwater in the shallower part of the coastal aquifer and group 2 groundwater in the deeper part; no group 3 groundwater is found along the eastern edge of the coastal aquifer. The distribution of the geochemical groups along $\mathrm{AA}^{\prime}$ suggests the subsurface in this part of the coastal aquifer can be separated into two predominant hydrostratigraphic layers. The shallow layer extends to a depth of about $200 \mathrm{~m}$ in 
the northern part of the aquifer and thins to less than 100 $\mathrm{m}$ in the southern part. On the basis of surficial geologic maps, the shallow layer represents Quaternary deposits and some or all of the underlying San Diego Formation.

The western section $\mathrm{BB}^{\prime}$ shows that the two predominant hydrostratigraphic layers extend to the coastline and get deeper in the south. The deepening of both groups 1 and 2 groundwater in the south may indicate structural deepening of the pull-apart basin and (or) significant erosion from the Tijuana River, the largest in San Diego County. In contrast to an absence on section $\mathrm{AA}^{\prime}$, group 3 groundwater is present along section $\mathrm{BB}^{\prime}$ and depicts zones of sea water intrusion in the northern part of aquifer and adjacent to the Sweetwater River. The occurrence of sea water intrusion along the San Diego Bay may reflect nearby groundwater pumping, a decrease in precipitation, or a rise in sea level.

\section{Conclusion}

The chemical and isotopic composition of groundwater from the San Diego area in southern California was investigated in order to determine the sources and movement of saline groundwater in the coastal aquifer and to aid in the initial mapping of the subsurface. $\mathrm{Cl}$ concentrations range from about 57 to $39,400 \mathrm{mg} / \mathrm{L}$, with the lowest concentrations at depths between about 150 and $250 \mathrm{~m}$, suggesting the greatest quantity of recharged groundwater may flow through this part of the coastal aquifer. On the basis of relative proportions of major-ions, the chemical composition of groundwater in the coastal aquifer is classified as $\mathrm{Na}-\mathrm{Ca}-\mathrm{Cl}-\mathrm{SO}_{4}, \mathrm{Na}-\mathrm{Cl}$, or Na-Ca-Cl type waters. $\delta^{2} \mathrm{H}$ and $\delta^{18} \mathrm{O}$ values indicate that groundwater in the coastal aquifer originates from at least three sources: (1) groundwater with intermediate isotopic values, characteristic of precipitation originating on coastal sediment, which flows in the shallower part of the coastal aquifer; (2) isotopically depleted groundwater, originating in the fractured crystalline rock more than $20 \mathrm{~km}$ east and upgradient from the coastline, which flows in the deeper part of the coastal aquifer; and (3) isotopically enriched groundwater, which reflects areas of sea water intrusion along the San Diego Bay.

${ }^{87} \mathrm{Sr} /{ }^{86} \mathrm{Sr}$ ratios range from about 0.7050 to 0.7090 and indicate that the groundwater encounters different geologic formations as it flows through the shallower and deeper parts of the coastal aquifer. ${ }^{3} \mathrm{H}$ and ${ }^{14} \mathrm{C}$ analyses indicate most groundwater in the coastal aquifer was recharged many thousands of years ago; very little groundwater in the coastal aquifer is modern $(<60$ years old). By using $\mathrm{Na} / \mathrm{Ca}$ ratios, in combination with $\mathrm{Cl}$ concentrations, $\delta^{18} \mathrm{O}$ values, ${ }^{87} \mathrm{Sr} /{ }^{86} \mathrm{Sr}$ ratios, and ${ }^{14} \mathrm{C}$ activities, we were able to identify groundwater considered to be the most representative of potable groundwater in the coastal San Diego area (group 1), saline groundwater resulting from "freshening" of a previously-saline aquifer (group 2 ), and saline groundwater resulting from sea water intrusion (group 3).
The geochemical approach used in this study was remarkably helpful, even in the absence of detailed subsurface geology, to determine the sources and movement of saline groundwater in a coastal aquifer. The many spatial and depth-dependent geochemical findings are aiding researchers and local water managers in mapping the subsurface, in developing a conceptual hydrogeologic framework, and in planning for additional desalination of brackish groundwater.

\section{Acknowledgments}

Funding for this study was provided by the Sweetwater Authority, the City of San Diego, the Otay Water District, the State of California via water bonds, and the United States Federal Government via appropriations for the USGS and for this study in particular. The authors are grateful to many individuals for their technical insights as well as to many USGS colleagues for their assistance in identifying, collecting, collating, reviewing, and preparing the data presented here. Their collective contribution to the study cannot be overstated. We also wish to thank the three anonymous reviewers for their helpful comments, which contributed significantly to the improvement of this manuscript.

\section{Supporting Information}

Supporting Information, including a list of the seven USGS multiple-depth monitoring-well sites and six domestic wells where water-quality samples were collected in San Diego County, California, and all the chemical and isotopic data for these sites, may be found in the online version of this article:

Table S1. List of the seven USGS multiple-depth monitoring-well sites and six domestic wells where waterquality samples were collected in San Diego County, California.

Table S2. Chemical data collected from the seven USGS multiple-depth monitoring-well sites and six domestic wells in San Diego County, California.

Table S3. Isotopic data collected from the seven USGS multiple-depth monitoring-well sites and six domestic wells in San Diego County, California.

\section{References}

Abbott, P.L. 1999. The Rise and Fall of San Diego. San Diego, California: Sunbelt Publications.

Andersen, M.S., V. Nyvang, R. Jakobsen, and D. Postma. 2005. Geochemical processes and solute transport at the seawater/freshwater interface of a sandy aquifer. Geochimica et Cosmochimica Acta 69, no. 16: 3979-3994.

Appelo, C.A.J., and D. Postma. 2005. Geochemistry, Groundwater and Pollution, 2nd ed. Rotterdam, The Netherlands: A.A. Balkema Publishers.

Bear, J., A.H. Cheng, S. Sorek, D. Ouazar, and I. Herrers (Eds). 1999. Seawater Intrusion in Coastal Aquifer Concepts, Methods, and Practices. London, UK: Kluwer Academic Publishers. 
Beukins, R.P. 1992. Radiometric accelerator mass spectrometry: Background, precision, and accuracy. In Radiocarbon After Four Decades, ed. R.E. Taylor, A. Long, and R.S. Kra. New York: Springer-Verlag.

California Department of Water Resources. 1967. Ground Water Occurrence and Quality. San Diego Region. Bulletin No. 106-2.

Capaccioni, B., M. Didero, C. Paletta, and L. Didero. 2005. Saline intrusion and refreshening in a multilayer coastal aquifer in the Catania Plain (Sicily, Southern Italy): dynamics of degradation processes according to the hydrochemical characteristics of groundwater. Journal of Hydrology 307: $1-16$.

Chen, K.P., and J.J. Jiao. 2007. Seawater intrusion and aquifer freshening near reclaimed coastal area near Shenzhen. Water Science and Technology 7: 137-145.

City of San Diego. 2011. 2010 Urban Water Management Plan. San Diego: City of San Diego.

Clark, I.D., and P. Fritz. 1997. Environmental Isotopes in Hydrogeology. Boca Raton, Florida: Lewis Publishers.

Coplen, T.B. 1994. Reporting of stable hydrogen, carbon, and oxygen isotopic abundances. Pure and Applied Chemistry 66: $273-276$.

Coplen, T.B., J.D. Wildman, and J. Chen. 1991. Improvements in the gaseous hydrogen-water equilibrium technique for hydrogen isotope analysis. Analytical Chemistry 63: 910-912.

Danskin, W.R., and C.D. Church. 2005. Determining age and vertical contribution of ground water pumped from wells in a small coastal river basin. A case study in the Sweetwater River Valley, San Diego County, California. USGS OpenFile Report 2005-1032. Reston, Virginia: USGS.

Davis, S.N., D.O. Whittemore, and J. Fabryka-Martin. 1998. Uses of chloride/bromide ratios in studies of potable water. Ground Water 36, no. 2: 338-350.

Ellis, A.J., and C.H. Lee. 1919. Geology and ground waters of the western part of San Diego County, California. USGS Water-Supply Paper 446. Reston, Virginia: USGS.

Epstein, S., and T.K. Mayeda. 1953. Variation of O-18 content of water from natural sources. Geochimica et Cosmochimica Acta 4: 213-224.

Fakir, Y., M. El Mernissi, T. Kreuser, and B. Berjami. 2002. Natural tracer approach to characterize groundwater in the coastal Sahel of Oualidia (Morocco). Environmental Geology 43: 197-202.

Faye, S., P. Maloszewski, W. Stichler, P. Trimborn, S.C. Faye, and C.B. Gaye. 2005. Groundwater salinization in the Saloum (Senegal) delta aquifer: minor elements and isotopic indicators. Science of the Total Environment 343: $243-259$.

Fishman, M.J. 1993. Methods of analysis by the U.S. Geological Survey National Water Quality Laboratory - Determination of inorganic and organic constituents in water and fluvial sediments. ISGS Open-File Report 93-125. Reston, Virginia: USGS.

Fishman, M.J., and L.C. Friedman. 1989. Methods for determination of inorganic substances in water and fluvial sediments. USGS Techniques of Water-Resources Investigations, book 5, chap. A1. Reston, Virginia: USGS.

Flint, L.E., A.L. Flint, B.J. Stolp, and W.R. Danskin. 2012. A basin-scale approach for assessing water resources in a semiarid environment: San Diego region, California and Mexico. Hydrology and Earth System Sciences 16: 3817-3833

Garbarino, J.R. 1999. Methods of analysis by the U.S. Geological Survey National Water Quality Laboratory-Determination of dissolved arsenic, boron, lithium, selenium, strontium, thallium, and vanadium using inductively coupled plasma-mass spectrometry. USGS Open-File Report 99-093. Reston, Virginia: USGS.
Gat, J.R., and R. Gonfiantini. 1981. Stable isotope hydrology, deuterium and oxygen-18 in the water cycle. Technical Reports Series No. 210. Vienna, Austria: IAEA.

Hanson, R.T., J.A. Izbicki, E.G. Reichard, B.D. Edwards, M. Land, and P. Martin. 2009. Comparison of Groundwater flow in Southern California coastal aquifers. In Earth Science in the Urban Ocean: The Southern Continental Borderland. Geological Society of America Special Paper 454 , ed. H.J. Lee, and W.R. Normark, 345-373. Boulder, Colorado: GSA.

Hem, J.D. 1985. Study and interpretation of the chemical characteristics of natural water. USGS Water-Supply Paper 2254, 3rd ed. Reston, Virginia: USGS

Huntley, D., S. Bickler, and C.M. Marshall. 1998. Distribution and hydrogeologic properties of the San Diego Formation, Southwestern San Diego County. San Diego County Water Authority, San Diego Formation Task Force, Report of Investigation.

Izbicki, J.A., A.H. Christensen, M.W. Newhouse, and G.R. Aiken. 2005. Inorganic, isotopic, and organic composition of high-chloride water from wells in a coastal southern California aquifer. Applied Geochemistry 20: 1496-1517.

Jones, B.F., A. Vengosh, E. Rosenthal, and Y. Yechiele. 1999. Geochemical investigation. In Seawater Intrusion in Coastal Aquifer Concepts, Methods, and Practices, ed. J. Bear, A.H. Cheng, S. Sorek, D. Ouazar, and I. Herrers. London, UK: Kluwer Academic Publishers.

Jørgensen, N.O., M.S. Andersen, and P. Engesgaard. 2008. Investigation of a dynamic seawater intrusion event using strontium isotopes $\left({ }^{87} \mathrm{Sr} /{ }^{86} \mathrm{Sr}\right)$. Journal of Hydrology 348 : 257-269.

Karlen, I., I.U. Olsson, P. Kallburg, and S. Kilici. 1964. Absolute determination of the activity of two ${ }^{14} \mathrm{C}$ dating standards. Arkiv Geofysik 4: 465-471.

Keller, B., and A. Ward. 2001. Tectonic setting of the San Diego formation aquifer, considered for conjunctive use storage. Journal of South American Earth Science 14: 533-540.

Lucas, L.L., and M.P. Unterweger. 2000. Comprehensive review and critical evaluation of the half-life of tritium. Journal of Research of the National Institutes of Standards and Technology 105, no. 4: 541-549.

Olsson, I.U. 1970. The use of Oxalic acid as a Standard. In Radiocarbon Variations and Absolute Chronology, ed. I.U. Olsson. New York: Wiley Interscience Division Publisher.

Prokoph, A., G.A. Sheilds, and J. Veized. 2008. Compilation and time-series analysis of a marine carbonate $\delta^{18} \mathrm{O}, \delta^{13} \mathrm{C}$, ${ }^{87} \mathrm{Sr} /{ }^{86} \mathrm{Sr}$, and $\delta^{34} \mathrm{~S}$ database through earth history. EarthScience Reviews 87: 113-133.

Ravenscroft, P., and J.M. McArthur. 2004. Mechanisms of regional enrichment of groundwater by boron: the examples of Bangladesh and Michigan, USA. Applied Geochemistry 19: $1413-1430$.

Richter, B.C., and C.W. Kreitler. 1993. Geochemical Techniques for Identifying Sources of Ground-Water Salinization. Boca Raton, Florida: C.R.C. Press, Inc.

Russak, A., and O. Sivan. 2010. Hydrogeochemical tool to identify salinization or freshening of coastal aquifers determined from combined field work, experiments, and modeling. Environmental Science and Technology v. 44: 4096-4102.

Shand, P., D.P.F. Darbyshire, A.J. Love, and W.M. Edmunds. 2009. Sr isotopes in natural waters: Applications to source characterization and water-rock interaction in contrasting landscapes. Applied Geochemistry 24: 574-586.

Stuiver, M. 1980. Workshop on ${ }^{14} \mathrm{C}$ data reporting. Radiocarbon 22: $964-966$.

Stuiver, M., and H.A. Polach. 1977. Discussion: Reporting of ${ }^{14} \mathrm{C}$ data. Radiocarbon 19: 355-363.

Thatcher, L.L., V.J. Janzer, and K.W. Edwards. 1977. Methods for the determination of radioactive substances in water. 
USGS Techniques of Water-Resources Investigations, book 5, chap. A5. Reston, Virginia: USGS.

U.S. Geological Survey. Variously dated. National field manual for the collection of water-quality data. USGS Techniques of Water-Resources Investigations, book 9, chap. A1-A9, Reston, Virginia: USGS. http://pubs.water.usgs.gov/ twri9A.

Vengosh, A., A.J. Spivack, Y. Artzi, and A. Ayalon. 1999. Geochemical and boron, strontium, and oxygen isotopic constraints on the origin of the salinity in groundwater from the Mediterranean coast of Israel. Water Resources Research 35: 1877-1894.

Vengosh, A., J. Gill, M.L. Davisson, and G.B. Hudson. 2002. A multi-isotope $(\mathrm{B}, \mathrm{Sr}, \mathrm{O}, \mathrm{H}$, and $\mathrm{C})$ and age dating $\left({ }^{3} \mathrm{H}-\right.$ ${ }^{3} \mathrm{He}$ and ${ }^{14} \mathrm{C}$ ) study of groundwater from Salinas Valley, California: Hydrochemistry, dynamics, and contamination processes. Water Resources Research 38, no. 1: 1008. DOI:10.1029/2001WR000517.
Vengosh, A., W. Kloppmann, A. Marei, Y. Livshitz, A. Gutierrez, M. Banna, C. Guerrot, I. Pankratov, and H. Raanan. 2005. Sources of salinity and boron in the Gaza strip: natural contaminant flow in the southern Mediterranean coastal aquifer. Water Resources Research 41: W01013. DOI:10.1029/2004WR003344.

Wigley, T.M.L., and A.B. Muller. 1981. Fractionation corrections in radiocarbon dating. Radiocarbon 23 , no. 2 : $173-190$.

Williams, A.E., and D.P. Rodoni. 1997. Regional isotope effects and application to hydrologic investigations in southwestern California. Water Resources Research 33, no. 7: $1721-1729$.

Wright, M.T., and K. Belitz. 2011. Status and understanding of groundwater quality in the San Diego Drainages Hydrogeologic Province, 2004-California GAMA Priority Basin Project. USGS Scientific Investigations Report 20115154. Reston, Virginia: USGS. 